\title{
ANALISIS RANTAI PASOK AGROINDUSTRI TEMPE DI KELURAHAN GUNUNG SULAH KECAMATAN WAY HALIM KOTA BANDAR LAMPUNG
}

\author{
(The analysis of supply chain of Tempe Agroindustry in Kelurahan Gunung Sulah \\ Kecamatan Way Halim Bandar Lampung City)
}

Zauvi Natasena Ajusa, Zainal Abidin, dan Eka Kasymir

\begin{abstract}
Jurusan Agribisnis, Fakultas Pertanian, Universitas Lampung, Jl. Prof. Dr. Soemantri Brojonegoro No. 1, Bandar Lampung, 35145, e-mail: zainal.abidin@fp.unila.ac.id
\end{abstract}

\begin{abstract}
This study aims to figure out the flow patterns and stakeholders of, supply chain performance of, and marketing efficiency of tempe agroindustry. Data collection was conducted in Gunung Sulah Subdistrict, Way Halim District, Bandar Lampung City from December 2018 to January 2019. This study uses a case study method. Determination of agroindustry sample uses purposive sampling technique and for supply chain sample uses snowball sampling technique. The data analysis method used for flow patterns and stakeholders are the supply chain system method, for the analysis of supply chain performance is Supply Chain Operation Reference (SCOR) 9.0 and for marketing efficiency analysis is the calculation of margin value, and the value of producer's share. The results of this study showed that supply chain of tempe agroindustry consisted of soybean importer, soybean agent, yeast and plastic wholesaler, soybean, yeast and plastic retailers, sub-agent of gas, producer of firewood, tempe's agroindustries, tempe retailers, and street vendors. There is an inefficiency in cost management of Cost of Goods Sold (COGS) metric for tempe products of tempe's agroindustry and asset management of Cash to Cash Cycle Time (CTCCT) metric for soybean, yeast, and fuel supply of tempe's agroindustry. The most efficient marketing of tempe's agroindustry is direct marketing to consumers with margin value of zero and producer's share value of $100 \%$.
\end{abstract}

Key words: margin, marketing, producer's share, supply chain, SCOR

\section{PENDAHULUAN}

Agroindustri merupakan usaha pengolahan hasil pertanian. Salah satu produk olahan hasil pertanian adalah tempe yang berbahan baku kedelai. Kedelai merupakan bahan pangan utama ketiga di Indonesia setelah padi dan jagung. Pemenuhan kebutuhan konsumen terhadap kedelai di Indonesia masih harus dipenuhi dengan cara impor. Industri pengolahan kedelai impor sudah banyak dilakukan baik di daerah pedesaan maupun di daerah perkotaan yang salah satunya adalah agroindustri tempe di Kelurahan Gunung Sulah Kecamatan Way Halim Kota Bandar Lampung.

Kelurahan Gunung Sulah merupakan sentra agroindustri tahu tempe di Kota Bandar Lampung, dengan jumlah agroindustri sebanyak 27 pengrajin tempe. Agroindustri Tempe di Kelurahan Gunung Sulah Kecamatan Way Halim Kota Bandar Lampung berkembang dengan melibatkan berbagai unit pengambil keputusan, baik yang bergerak pada aliran bahan baku maupun pada produk hasil olahan yang secara keseluruhan terancang dalam sebuah sistem rantai pasok.
Konsep manajemen rantai pasok menekankan pada pola yang terintegrasi dalam proses aliran produksi mulai dari bahan mentah sampai produk tiba di tangan konsumen. Peranan rantai pasok agroindustri tempe Kelurahan Gunung Sulah Kecamatan Way Halim Kota Bandar Lampung meliputi pengadaan bahan baku kedelai dari produsen hingga ke agroindustri tempe kemudian yang mengolah menjadi produk tempe yang di distribusikan sampai ke tangan konsumen akhir. Manajemen rantai pasok yang tidak berjalan dengan baik dapat diminimalisir dengan dilakukannya pengukuran kinerja rantai pasok itu sendiri. Pengukuran kinerja rantai pasok akan memberikan peluang besar untuk memperbaiki dan mengembangkan manajemen rantai pasok pada semua industri (Bolstorff 2003).

Pemasaran dapat meningkatkan pendapatan produsen dan lembaga-lembaga penyaluran produk tempe. Salah satu indikator keberhasilan pemasaran tempe adalah sistem pemasaran yang berlangsung secara efisien dan mampu mengalirkan produk dengan biaya seminimal mungkin, tingkat harga dan keuntungan yang baik. 
Selain itu, besar kecilnya bagian yang diterima produsen (producer's share) akan menunjukkan apabila suatu sistem pemasaran berjalan efisien.

Berdasarkan uraian tersebut, maka tujuan dari penelitian ini adalah mengetahui pola alir dan para pihak rantai pasok agroindustri tempe Kelurahan Gunung Sulah, mengetahui kinerja rantai pasok agroindustri tempe Kelurahan Gunung Sulah, mengetahui saluran pemasaran yang efisien pada agroindustri tempe Kelurahan Gunung Sulah.

\section{METODE PENELITIAN}

Penelitian ini menggunakan metode studi kasus. Metode studi kasus adalah salah satu metode penelitian yang dilakukan secara intensif, terperinci dan mendalam terhadap suatu individu, lembaga tertentu dengan daerah atau subjek yang sempit selama kurun waktu tertentu (Arikunto 2004). Metode studi kasus digunakan untuk memperoleh data secara lengkap dan rinci pada agroindustri tempe mengenai rantai pasok dan efisiensi pemasaran produk yang dihasilkan agroindustri tempe.

Sampel pelaku agroindustri tempe ditentukan dengan teknik purposive sampling berdasarkan pertimbangan kelompok populasi dengan skala produksi besar, produksi sedang, dan produksi kecil. Pengambilan sampel lainnya untuk pelaku rantai pasok agroindustri tempe meliputi pemasok kedelai, pedagang tempe, dan pedagang kaki lima dilakukan menggunakan snowball sampling dengan pertimbangan karena tidak ada informasi yang pasti mengenai jumlah pemasok bahan baku, pedagang tempe dan pedagang kaki lima.

Metode analisis data yang digunakan untuk mengetahui pola alir dan para pihak rantai pasok adalah metode sistem rantai pasok. Metode sistem rantai pasok bertujuan untuk menemukan pengetahuan yang luas terhadap objek penelitian tertentu yang diteliti melalui data sampel.

Metode analisis untuk menjawab tujuan kedua dengan mengukur kinerja rantai pasok adalah dengan Supply Chain Operation References (SCOR) 9.0 version yang merupakan model pengukuran kinerja yang dikeluarkan oleh Supply Chain Council. Pengukuran kinerja rantai pasok untuk skala industri kecil hanya dilakukan pengukuran pada level satu yang terdiri dari empat atribut dan empat metrik yang telah ditentukan untuk pengukuran kinerja yang terlihat pada Tabel 1 .
Tabel 1. Parameter atribut dan metrik kinerja rantai pasok

\begin{tabular}{|c|c|c|c|c|c|}
\hline \multirow{2}{*}{$\begin{array}{l}\text { Atribut } \\
\text { Kinerja }\end{array}$} & \multirow{2}{*}{ Metrik } & \multirow{2}{*}{$\begin{array}{c}\text { Data } \\
\text { Aktual }\end{array}$} & \multicolumn{3}{|c|}{ Benchmark } \\
\hline & & & Parity & Advantag & Superior \\
\hline Reliabilitas & POF & & $\%$ & $\%$ & $\%$ \\
\hline Responsivitas & OFCT & & Hari & Hari & Hari \\
\hline $\begin{array}{l}\text { Manajemen } \\
\text { Biaya }\end{array}$ & COGS & & $\%$ & $\%$ & $\%$ \\
\hline $\begin{array}{l}\text { Manajemen } \\
\text { Aset }\end{array}$ & СТCCT & & Hari & Hari & Hari \\
\hline
\end{tabular}

a) Perfect Order Fulfillment (POF)

$$
\text { POF }=\frac{\text { Total pesanan sempurna }}{\text { Total pesanan }} \times 100 \% \text {. }
$$

b) Order Fulfillment Cycle-Time (OFCT)

OFCT $=$ Waktu Pemesanan + Waktu Penerimaan.

c) Cost of Goods Sold (COGS)

$$
\begin{aligned}
\text { COGS }= & \text { Inventori awal }+ \text { Pembelian } \\
& \text { selama periode }- \text { inventori akhir.... }
\end{aligned}
$$

d) Cash to Cash Cycle Time (CTCCT)

$$
\begin{aligned}
\text { CTCCT }= & \text { Persediaan pasokan harian }+ \\
& \text { Rata-rata piutang harian }- \\
& \text { Rata-rata hutang harian.................. }
\end{aligned}
$$

Setelah dihitung kinerja aktual rantai pasok agroindustri tempe, selanjutnya data aktual tersebut dibandingkan dengan benchmark yang telah ditetapkan oleh Supply Chain Council (2008) untuk industri makanan. Kriteria benchmark terdiri dari parity yaitu klasifikasi terendah target efisiensi kinerja, advantage yaitu klasifikasi menengah target efisiensi kinerja, dan superior yaitu klasifikasi tertinggi target efisiensi kinerja.

Pengujian efisiensi pemasaran dilakukan untuk mengetahui saluran pemasaran yang efisien pada agroindustri tempe. Pengujian dilakukan menggunakan perhitungan marjin pemasaran, producer's share dan RPM. Marjin pemasaran adalah selisih harga di tingkat produsen dengan harga di tingkat pengecer yang terdiri dari keuntungan dan biaya (Hasyim 2012). Secara matematis marjin pemasaran dirumuskan sebagai berikut:

$$
\mathrm{Mji}=\mathrm{Psi}-\mathrm{Pbi} .
$$


Keterangan :

Mji = Marjin lembaga pemasaran tingkat ke-i

Psi = Harga penjualan lembaga pemasaran tingkat ke-i $(\mathrm{i}=1,2,3, \ldots ., \mathrm{n})$

$\mathrm{Pbi}=$ Harga pembelian lembaga pemasaran tingkat ke-i

Penyebaran marjin pemasaran dapat dilihat berdasarkan presentase keuntungan terhadap biaya pemasaran atau Ratio Profit Margin (RPM) pada masing-masing lembaga pemasaran, yang dirumuskan sebagai berikut:

$$
\mathrm{RPM}=\frac{\pi \mathrm{i}}{\mathrm{bti}}
$$

Keterangan :

Bti = Biaya pemasaran lembaga pemasaran tingkat ke-i

Пi $=$ Keuntungan lembaga pemasaran tingkat ke-i

Nilai RPM yang relatif menyebar merata pada berbagai tingkat lembaga perantara pemasaran merupakan cerminan dari sistem pemasaran yang efisien. Jika selisih RPM antara lembaga perantara pemasaran sama dengan nol, maka sistem pemasaran tersebut efisien, dan jika selisih RPM antara lembaga perantara pemasaran tidak sama dengan nol, maka sistem pemasaran tidak efisien (Azzaino 1983).

Menurut Abidin, Harahab, dan Asmarawati (2017) menyatakan bahwa saluran pemasaran dianggap efisien apabila saluran pemasaran tersebut mempunyai producer's share lebih dari $50,00 \%$. Bagian yang diterima producer's share dapat dirumuskan (Asmarantaka 2014):

$$
\text { Producer's share }=\frac{\mathrm{Pf}}{\mathrm{Pr}} \times 100 \%
$$

\author{
Keterangan : \\ Producer's share = Bagian yang diterima \\ produsen \\ Pf \\ $=$ Harga tempe di tingkat \\ produsen \\ $\operatorname{Pr}$ \\ $=$ Harga tempe di tingkat \\ konsumen
}

\section{HASIL DAN PEMBAHASAN}

\section{Agroindustri Tempe}

Agroindustri tempe di Kelurahan Gunung Sulah pertama kali diusahakan pada Tahun 1962. Pendiri agroindustri tempe berasal dari penduduk transmigrasi dari Provinsi Jawa Tengah. Agroindustri tempe terdiri dari skala produksi besar sebesar 100 kilogram, skala produksi sedang sebesar 65 kilogram, dan skala produksi kecil sebesar 50 kilogram. Agroindustri tempe skala besar memiliki tenaga kerja dalam keluarga sebanyak lima orang, agroindustri tempe skala sedang memiliki tenaga kerja dalam keluarga sebanyak empat orang, dan agroindustri tempe skala kecil memiliki tenaga kerja sebanyak dua orang. Ketiga agroindustri memiliki jumlah tenaga kerja luar keluarga yang sama yaitu sebanyak satu orang.

\section{Stakeholder}

Manajemen rantai pasok melibatkan berbagai pihak agar rantai pasok dapat berjalan dengan baik, dengan memilih pemasok yang tepat maka perusahaan akan terhindar dari kekosongan atau kerusakan barang (Indrajit dan Djokopranoto 2002). Pihak-pihak yang terlibat dengan agroindustri tempe telah disajikan pada Tabel 2.

\begin{tabular}{|c|c|c|}
\hline Nama & Alamat & Fungsi \\
\hline FKS Multi Agro & $\begin{array}{l}\text { Jl. Ir. Sutami, Tanjung Bintang, } \\
\text { Lampung Selatan }\end{array}$ & Importir kedelai, penyedia kedelai bagi konsumen \\
\hline Agen kedelai & Kecamatan Kedamaian & $\begin{array}{l}\text { Lembaga penyalur kedelai dari importir ke pedagang pengecer dan } \\
\text { agroindustri }\end{array}$ \\
\hline $\begin{array}{l}\text { Pedagang pengecer } \\
\text { kedelai }\end{array}$ & Kelurahan Gunung Sulah & Memenuhi kebutuhan kedelai untuk agroindustri \\
\hline Agroindustri tempe & Kelurahan Gunung Sulah & $\begin{array}{l}\text { Memproduksi dan memenuhi kebutuhan tempe untuk pedagang } \\
\text { pengecer dan konsumen akhir }\end{array}$ \\
\hline $\begin{array}{l}\text { Pedagang pengecer } \\
\text { tempe }\end{array}$ & $\begin{array}{l}\text { Pasar Natar, Branti, Tegineneng, } \\
\text { dan Jatimulyo }\end{array}$ & Menjual tempe untuk pedagang kaki lima dan konsumen akhir \\
\hline Pedagang kaki lima & $\begin{array}{l}\text { Natar, Tegineneng dan Tanjung } \\
\text { Senang }\end{array}$ & $\begin{array}{l}\text { Memproduksi dan memenuhi kebutuhan tempe goreng untuk } \\
\text { konsumen akhir }\end{array}$ \\
\hline
\end{tabular}

Tabel 2. Stakeholder rantai pasok agroindustri tempe 
Tabel 3. Hasil analisis kinerja rantai pasok agroindustri tempe

\begin{tabular}{|c|c|c|c|c|c|c|c|}
\hline \multicolumn{8}{|c|}{ Rantai Pasok Kedelai } \\
\hline \multirow{2}{*}{ Atribut Kinerja } & \multirow{2}{*}{ Metrik } & \multicolumn{3}{|c|}{ Data Aktual Agroindustri } & \multicolumn{3}{|c|}{ Benchmark } \\
\hline & & Besar & Sedang & Kecil & Parity & Advantage & Superior \\
\hline Reliabilitas (\%) & POF & 98,00 & 98,00 & 98,00 & 74,00 & 81,00 & 88,00 \\
\hline Responsivitas (hari) & OFCT & 4,00 & 2,00 & 1,00 & 14,00 & 8,00 & 2,00 \\
\hline Manajemen biaya (\%) & COGS & 66,33 & 59,42 & 58,13 & 69,00 & 61,00 & 53,00 \\
\hline Manajemen aset (hari) & CTCCT & 10,00 & 6,00 & 30,00 & 29,00 & 21,00 & 13,00 \\
\hline \multicolumn{8}{|c|}{ Rantai Pasok Tempe } \\
\hline \multirow{2}{*}{ Atribut Kinerja } & \multirow{2}{*}{ Metrik } & \multicolumn{3}{|c|}{ Data Aktual Agroindustri } & \multicolumn{3}{|c|}{ Benchmark } \\
\hline & & Besar & Sedang & Kecil & Parity & Advantage & Superior \\
\hline Reliabilitas (\%) & POF & 100,00 & 100,00 & 100,00 & 74,00 & 81,00 & 88,00 \\
\hline Responsivitas (hari) & OFCT & 1,00 & 1,00 & 1,00 & 14,00 & 8,00 & 2,00 \\
\hline Manajemen biaya (\%) & COGS & 82,14 & 75,70 & 76,03 & 69,00 & 61,00 & 53,00 \\
\hline Manajemen aset (hari) & СТCСТ & 3,00 & 3,00 & 3,00 & 29,00 & 21,00 & 13,00 \\
\hline \multicolumn{8}{|l|}{ Keterangan : } \\
\hline $\begin{array}{ll}\mathrm{POF} & =\text { Perfect } \text { Order } \\
\text { OFCT } & =\text { Order Fulfill }\end{array}$ & & & & & & & \\
\hline $\begin{array}{l}=\text { Order Fulfill } \\
=\text { Cost of Good }\end{array}$ & & & & & & & \\
\hline$=$ Cash to Cash & & & & & & & \\
\hline
\end{tabular}

\section{Pola Rantai Pasok}

Pola rantai pasok agroindustri tempe terdiri dari pola rantai pasok kedelai, ragi, plastik, bahan bakar dan tempe, namun penulis hanya membahas tentang kinerja rantai pasok kedelai dan tempe.

\section{Rantai Pasok Kedelai}

Saluran I : Importir $\longrightarrow$ Agen $\rightarrow$ Agroindustri Saluran II : Importir Kedelai $\rightarrow$ Agen $\longrightarrow$ Pedagang Pengecer $\rightarrow$ Agroindustri

\section{Rantai Pasok dari hulu ke hilir Agroindustri Tempe}

Saluran I : pemasok bahan baku $\rightarrow$ agroindustri tempe $\rightarrow$ pedagang pengecer tempe $\rightarrow$ pedagang kaki lima (konsumen)

Saluran II : pemasok bahan baku $\rightarrow$ agroindustri tempe $\rightarrow$ pedagang pengecer tempe $\rightarrow$ konsumen

Saluran III : pemasok bahan baku $\rightarrow$ agroindustri tempe $\rightarrow$ konsumen

\section{Kinerja Rantai Pasok Agroindustri Tempe}

Kinerja rantai pasok agroindustri tempe terdiri dari kinerja rantai pasok kedelai, ragi, plastik, bahan bakar dan tempe, namun penulis hanya membahas tentang kinerja rantai pasok kedelai dan tempe.

\section{Kinerja Rantai Pasok Kedelai}

Berdasarkan Tabel 3 terlihat bahwa kinerja rantai pasok kedelai pada agroindustri tempe skala kecil atribut kinerja manajemen aset metrik CTCCT berada di bawah target kinerja yang telah ditetapkan, hal ini menunjukkan bahwa kinerja rantai pasok agroindustri tempe atribut manajemen aset terhadap penggunaan kedelai adalah tidak efisien. Kinerja rantai pasok kedelai atribut kinerja dan metrik lainnya sudah berada di target kinerja yang telah ditetapkan, dua diantaranya yaitu metrik POF dan OFCT berada di klasifikasi superior.

Penelitian ini sejalan dengan penelitian Lestari, Abidin, dan Suarno (2016) dimana tidak boleh ada dua kinerja superior untuk satu produk yang diukur kinerjanya. Berdasarkan penelitian Mutakin (2010) penetapan klasifikasi kinerja rantai pasok ditentukan dari nilai bobot terbesar, sehingga metrik POF ditetapkan sebagai kinerja klasifikasi superior, metrik OFCT ditetapkan sebagai kinerja klasifikasi advantage, metrik COGS dan metrik CTCCT ditetapkan sebagai kinerja klasifikasi parity, namun untuk metrik CTCCT pada agroindustri skala kecil belum mencapai standar target kinerja.

\section{Kinerja Rantai Pasok Tempe}

Tabel 3 terlihat kinerja rantai pasok tempe pada atribut kinerja reliabilitas, responsitivitas dan manajamen aset telah mencapai target yang telah ditetapkan dan ketiga atribut berada pada klasifikasi superior, sedangkan kinerja rantai pasok tempe atribut manajemen biaya metrik COGS mengalami ketidakefisienan. Diperlukan perhatian kinerja pada atribut manajemen biaya metrik COGS, agar standar kinerja yang telah ditetapkan dapat tercapai. 
Tabel 4. Analisis efisiensi pemasaran agroindustri skala besar

\begin{tabular}{|c|c|c|c|c|c|c|c|c|c|c|}
\hline \multirow{3}{*}{ No } & \multirow{3}{*}{ Jenis Lembaga Pemasaran } & \multicolumn{9}{|c|}{$\begin{array}{c}\text { Saluran Pemasaran } \\
\text { (Rp/bungkus) }\end{array}$} \\
\hline & & \multicolumn{3}{|c|}{ I } & \multicolumn{3}{|c|}{ II } & \multicolumn{3}{|c|}{ III } \\
\hline & & A & B & $\mathrm{C}$ & A & $\mathrm{B}$ & $\mathrm{C}$ & A & B & $\mathrm{C}$ \\
\hline \multirow[t]{9}{*}{1} & Produsen & & & & & & & & & \\
\hline & Harga Jual & $1.250,00$ & & & $1.250,00$ & 400,00 & 666,70 & $2.500,00$ & $1.000,00$ & $1.250,00$ \\
\hline & Biaya & & & & & & & & & \\
\hline & - produksi & 355,20 & & & 355,20 & 355,20 & 355,20 & 355,20 & 355,20 & 355,20 \\
\hline & - pemasaran & 7,40 & & & 7,40 & 7,40 & 7,40 & & & \\
\hline & - tenaga Kerja & 72,00 & & & 72,00 & 72,00 & 72,00 & 72,00 & 72,00 & 72,00 \\
\hline & Jumlah Biaya & 434,60 & & & 434,60 & 434,60 & 434,60 & 427,20 & 427.20 & 427,20 \\
\hline & Keuntungan & 815,40 & & & 815,40 & $-34,60$ & 232,10 & $2,072,80$ & 572,80 & 822,80 \\
\hline & RPM & 1,90 & & & 1,90 & $-0,10$ & 0,50 & 4,90 & 1,30 & 1,90 \\
\hline \multirow[t]{9}{*}{2} & Pedagang Pengecer & & & & & & & & & \\
\hline & Harga Beli & $1.250,00$ & & & $1.250,00$ & 400,00 & 666,70 & & & \\
\hline & Biaya & & & & & & & & & \\
\hline & - retribusi & 33,30 & & & 33,30 & 33,30 & 33,30 & & & \\
\hline & Jumlah Biaya & 33,30 & & & 33,30 & 33,30 & 33,30 & & & \\
\hline & Harga Jual & $2.500,00$ & & & $3.000,00$ & 833,00 & $1.667,00$ & & & \\
\hline & Keuntungan & $1.216,70$ & & & 1.716 .70 & 399,70 & 967,00 & & & \\
\hline & Marjin & $1.250,00$ & & & $1.750,00$ & 433,00 & $1.000,30$ & & & \\
\hline & RPM & 36,50 & & & 51,50 & 12,00 & 29,00 & & & \\
\hline \multirow[t]{9}{*}{3} & Pedagang Kaki Lima & & & & & & & & & \\
\hline & Harga Beli & $2.500,00$ & & & & & & & & \\
\hline & Biaya & & & & & & & & & \\
\hline & - produksi & $1.250,00$ & & & & & & & & \\
\hline & Jumlah Biaya & $1.250,00$ & & & & & & & & \\
\hline & Harga Jual & $5.333,00$ & & & & & & & & \\
\hline & Keuntungan & $1.583,00$ & & & & & & & & \\
\hline & Marjin & $2.833,00$ & & & & & & & & \\
\hline & RPM & 1,30 & & & & & & & & \\
\hline \multirow[t]{2}{*}{4} & Konsumen & & & & & & & & & \\
\hline & Harga Beli & $5.333,00$ & & & $3.000,00$ & 833,00 & $1.667,00$ & $2.500,00$ & $1.000,00$ & $1.250,00$ \\
\hline 5 & Total Marjin Pemasaran & $4.083,00$ & & & $1.750,00$ & 433,00 & $1.000,30$ & 0,00 & 0,00 & 0,00 \\
\hline 6 & Tot. Marjin Pemasaran (\%) & 76,60 & & & 58.30 & 52,00 & 60,00 & 0,00 & 0,00 & 0,00 \\
\hline 7 & Producer's share $(\%)$ & 23,40 & & & 41,70 & 48,00 & 40,00 & 100,00 & 100,00 & 100,00 \\
\hline
\end{tabular}

Keterangan :

$\mathrm{A}=$ tempe ukuran $16 \times 10 \mathrm{~cm}$

$\mathrm{B}=$ tempe ukuran $13 \times 11 \mathrm{~cm}$

$\mathrm{C}=$ tempe ukuran $16 \times 4 \mathrm{~cm}$

Penelitian ini sejalan dengan penelitian Lestari, Abidin, dan Suarno (2016) dimana tidak boleh ada dua kinerja superior untuk satu produk yang diukur kinerjanya. Berdasarkan penelitian Mutakin (2010) penetapan klasifikasi kinerja rantai pasok ditentukan dari nilai bobot terbesar, sehingga metrik POF ditetapkan sebagai kinerja klasifikasi superior, metrik OFCT ditetapkan sebagai kinerja klasifikasi advantage, dan metrik CTCCT ditetapkan sebagai kinerja klasifikasi parity, namun untuk metrik COGS pada agroindustri tempe belum mencapai standar target kinerja.

\section{Efisiensi Pemasaran}

Pemasaran yang dilakukan agroindustri tempe memiliki tiga saluran. Saluran pertama merupakan pemasaran yang ditujukan ke konsumen akhir melalui lembaga perantara seperti pedagang pengecer dan pedagang kaki lima. Saluran kedua merupakan pemasaran ke konsumen akhir melalui pedagang pengecer, sedangkan saluran ketiga merupakan pemasaran ke konsumen akhir secara langsung oleh agroindustri tempe.

\section{Pemasaran Agroindustri Tempe Skala Besar}

Berdasarkan Tabel 4 menunjukkan bahwa nilai persentase marjin saluran pertama sebesar $76,60 \%$ dan saluran kedua sebesar $58,30 \%, 52,00 \%$, dan $60,00 \%$. 
Tabel 5. Analisis efisiensi pemasaran agroindustri skala sedang

\begin{tabular}{|c|c|c|c|c|c|c|c|c|c|c|}
\hline \multirow{3}{*}{ No } & \multirow{3}{*}{ Jenis Lembaga Pemasaran } & \multicolumn{9}{|c|}{$\begin{array}{l}\text { Saluran Pemasaran } \\
\text { (Rp/bungkus) }\end{array}$} \\
\hline & & \multicolumn{3}{|c|}{ I } & \multicolumn{3}{|c|}{ II } & \multicolumn{3}{|c|}{ III } \\
\hline & & A & B & $\mathrm{C}$ & A & $\mathrm{B}$ & $\mathrm{C}$ & A & $\mathrm{B}$ & $\mathrm{C}$ \\
\hline \multirow[t]{9}{*}{1} & Produsen & & & & & & & & & \\
\hline & Harga Jual & & 350,00 & & $1.250,00$ & 350,00 & $1.250,00$ & $2.500,00$ & 714,00 & $2.000,00$ \\
\hline & Biaya & & & & & & & & & \\
\hline & - produksi & & 565,00 & & 565,00 & 565,00 & 565,00 & 565,00 & 565.00 & 565,00 \\
\hline & - pemasaran & & 8,50 & & 8,50 & 8,50 & 8,50 & & & \\
\hline & - tenaga Kerja & & 171,20 & & 171,20 & 171,20 & 171,20 & 171,20 & 171,20 & 171,20 \\
\hline & Jumlah Biaya & & 744,70 & & 744,70 & 744,70 & 744,70 & 736,20 & 736,20 & 736,20 \\
\hline & Keuntungan & & $-394,70$ & & 505,30 & $-394,70$ & 505,30 & $1.763,80$ & $-22,20$ & $1.263,80$ \\
\hline & RPM & & $-0,50$ & & 0,70 & $-0,50$ & 0.70 & 2,40 & 0,00 & 1,70 \\
\hline \multirow[t]{9}{*}{2} & Pedagang Pengecer & & & & & & & & & \\
\hline & Harga Beli & & 350,00 & & $1.250,00$ & 350,00 & $1.250,00$ & & & \\
\hline & Biaya & & & & & & & & & \\
\hline & - retribusi & & 33,30 & & 33,30 & 33,30 & 33,30 & & & \\
\hline & Jumlah Biaya & & 33,30 & & 33,30 & 33,30 & 33,30 & & & \\
\hline & Harga Jual & & 633,00 & & $3.000,00$ & 833,00 & $1.667,00$ & & & \\
\hline & Keuntungan & & 249,70 & & $1.716,70$ & 249,70 & 383,70 & & & \\
\hline & Marjin & & 283,00 & & $1.750,00$ & 483,00 & 417,00 & & & \\
\hline & RPM & & 7,50 & & 51,50 & 7,50 & 11,50 & & & \\
\hline \multirow[t]{9}{*}{3} & Pedagang Kaki Lima & & & & & & & & & \\
\hline & Harga Beli & & 633,00 & & & & & & & \\
\hline & Biaya & & & & & & & & & \\
\hline & - produksi & & 333,30 & & & & & & & \\
\hline & Jumlah Biaya & & 333,30 & & & & & & & \\
\hline & Harga Jual & & $2.000,00$ & & & & & & & \\
\hline & Keuntungan & & $1.033,70$ & & & & & & & \\
\hline & Mariin & & 1.367 .00 & & & & & & & \\
\hline & RPM & & 3,10 & & & & & & & \\
\hline \multirow[t]{2}{*}{4} & Konsumen & & & & & & & & & \\
\hline & Harga Beli & & $2.000,00$ & & $3.000,00$ & 833,00 & $1.667,00$ & $2.500,00$ & 714,00 & $2.000,00$ \\
\hline 5 & Total Marjin Pemasaran & & $1.650,00$ & & $1.750,00$ & 483,00 & 417,00 & 0,00 & 0,00 & 0,00 \\
\hline 6 & Tot. Marjin Pemasaran (\%) & & 82,50 & & 58,30 & 58,00 & 25,00 & 0,00 & 0,00 & 0,00 \\
\hline 7 & Producer's share $(\%)$ & & 17,50 & & 41,70 & 42,00 & 75,00 & 100,00 & 100.00 & 100,00 \\
\hline
\end{tabular}

Keterangan :

$\mathrm{A}=$ tempe ukuran $16 \times 10 \mathrm{~cm}$

$\mathrm{B}=$ tempe ukuran $10 \times 9 \mathrm{~cm}$

$\mathrm{C}=$ tempe ukuran $20 \times 4 \mathrm{~cm}$

Nilai persentase producer's share saluran pertama sebesar $23,40 \%$ dan saluran kedua sebesar $41,70 \%$, $48,00 \%$ dan $40,00 \%$. Nilai RPM saluran pertama dan kedua memiliki nilai relatif tidak menyebar merata pada masing-masing lembaganya, sehingga dapat dikatakan bahwa pemasaran saluran pertama dan kedua agroindustri tempe skala besar tidak efisien, sedangkan pada saluran ketiga menunjukkan bahwa nilai peresentase margin pemasaran sebesar nol dan nilai persentase producer's share sebesar $100,00 \%$, serta nilai RPM tidak dapat dibandingkan dengan lembaga lainnya dikarenakan pemasaran dilakukan secara langsung ke konsumen tanpa adanya lembaga perantara, sehingga dapat dikatakan bahwa pemasaran saluran ketiga pada agroindustri tempe skala besar adalah efisien.

\section{Pemasaran Agroindustri Tempe Skala Sedang}

Berdasarkan Tabel 5 menunjukkan bahwa nilai persentase marjin saluran pertama sebesar $82,50 \%$ dan saluran kedua sebesar $58,30 \%, 58,00 \%$, dan 25,00\%.Nilai persentase producer's share saluran pertama sebesar $17,50 \%$ dan saluran kedua sebesar $41,70 \%, 42,00 \%$ dan $75,00 \%$. Nilai RPM saluran pertama dan kedua memiliki nilai relatif tidak menyebar merata pada masing-masing lembaganya, sehingga dapat dikatakan bahwa pemasaran saluran pertama dan kedua agroindustri tempe skala sedang tidak efisien, sedangkan pada saluran ketiga, menunjukkan bahwa nilai peresentase margin pemasaran sebesar nol dan nilai persentase producer's share sebesar $100,00 \%$, serta nilai RPM tidak dapat dibandingkan dengan lembaga lainnya dikarenakan pemasaran dilakukan secara langsung. 
Tabel 6. Analisis efisiensi pemasaran agroindustri skala kecil

\begin{tabular}{|c|c|c|c|c|}
\hline \multirow{3}{*}{ No } & \multirow{3}{*}{ Jenis Lembaga Pemasaran } & \multicolumn{3}{|c|}{$\begin{array}{l}\text { Saluran Pemasaran } \\
\text { (Rp/bungkus) }\end{array}$} \\
\hline & & I & II & III \\
\hline & & Tempe Uk. $12 \times 12 \mathrm{~cm}$ & Tempe Uk. $12 \times 12 \mathrm{~cm}$ & Tempe Uk. $12 \times 12 \mathrm{~cm}$ \\
\hline \multirow[t]{9}{*}{1} & Produsen & & & \\
\hline & Harga Jual & 714,00 & 714,00 & $1.000,00$ \\
\hline & Biaya & & & \\
\hline & - produksi & 504,70 & 504,70 & 504,70 \\
\hline & - pemasaran & 7,40 & 7,40 & \\
\hline & - tenaga Kerja & 144,90 & 144,90 & 144,90 \\
\hline & Jumlah Biaya & 657,00 & 657,00 & 649,60 \\
\hline & Keuntungan & 57,00 & 57,00 & 350,40 \\
\hline & RPM & 0,10 & 0,10 & 0,50 \\
\hline \multirow[t]{9}{*}{2} & Pedagang Pengecer & & & \\
\hline & Harga Beli & 714,00 & 714,00 & \\
\hline & Biaya & & & \\
\hline & - retribusi & 50,00 & 50,00 & \\
\hline & Jumlah Biaya & 50,00 & 50,00 & \\
\hline & Harga Jual & $1.250,00$ & $1.667,00$ & \\
\hline & Keuntungan & 486,00 & 903,00 & \\
\hline & Marjin & 536,00 & 953,00 & \\
\hline & RPM & 9,70 & 18,10 & \\
\hline \multirow[t]{9}{*}{3} & Pedagang Kaki Lima & & & \\
\hline & Harga Beli & $1.250,00$ & & \\
\hline & Biaya & & & \\
\hline & - produksi & 333,30 & & \\
\hline & Jumlah Biaya & 333,30 & & \\
\hline & Harga Jual & $2.000,00$ & & \\
\hline & Keuntungan & 416,70 & & \\
\hline & Marjin & 750,00 & & \\
\hline & RPM & 1,30 & & \\
\hline \multirow[t]{2}{*}{4} & Konsumen & & & \\
\hline & Harga Beli & $2.000,00$ & $1.667,00$ & $1.000,00$ \\
\hline 5 & Total Marjin Pemasaran & $1.286,00$ & 953,00 & 0,00 \\
\hline 6 & Tot. Marjin Pemasaran (\%) & 64,30 & 57,20 & 0,00 \\
\hline 7 & Producer's share $(\%)$ & 35,70 & 42,80 & 100,00 \\
\hline
\end{tabular}

ke konsumen tanpa adanya lembaga perantara, sehingga dapat dikatakan bahwa pemasaran saluran ketiga pada agroindustri tempe skala sedang adalah efisien.

\section{Pemasaran Agroindustri Tempe Skala Kecil}

Berdasarkan Tabel 6 menunjukkan bahwa nilai persentase marjin saluran pertama dan kedua sebesar $64,30 \%$ dan $57,20 \%$. Nilai persentase producer's share saluran pertama dan kedua sebesar $35,70 \%$ dan $42,80 \%$. Nilai RPM saluran

pertama dan kedua memiliki nilai yang relatif tidak menyebar merata pada masing-masing lembaganya, sehingga dapat dikatakan bahwa pemasaran saluran pertama dan kedua agroindustri tempe skala kecil tidak efisien, sedangkan pada saluran ketiga, menunjukkan bahwa agroindustri tempe skala kecil saluran ketiga adalah efisien, dikarenakan saluran ini memiliki nilai persentase total margin sebesar nol dan nilai persentase producer's share sebesar $100,00 \%$, serta nilai RPM tidak dapat dibandingkan dengan lembaga lainnya karena agroindustri melakukan penjualan langsung ke konsumen akhir.

Secara keseluruhan saluran pemasaran dari agroindustri tempe penelitian ini adalah sebanyak tiga pola saluran pemasaran. Pemasaran saluran ketiga yaitu pemasaran langsung ke konsumen merupakan pemasaran yang efisien pada agroindustri tempe. Penelitian ini sejalan dengan penelitian Noviantari, Hasyim, dan Rosanti (2015) bahwa pemasaran dari agroindustri langsung ke konsumen akhir merupakan saluran pemasaran yang paling efisien, namun penelitian ini tidak sejelan dengan penelitian Nilawati (2015) bahwa pemasaran tempe yang paling efisien adalah pemasaran melalui pedagang pengecer, hal ini dikarenakan penelitian yang dilakukannya tidak memiliki saluran pemasaran langsung ke konsumen akhir, sedangkan penelitian ini memiliki saluran pemasaran langsung ke konsumen akhir. 


\section{KESIMPULAN}

Pola rantai pasok kedelai terdiri dari importir kedelai $\longrightarrow$ agen kedelai $\longrightarrow$ pedagang pengecer $\longrightarrow$ agroindustri tempe. Pola rantai pasok tempe terdiri dari pemasok bahan baku $\longrightarrow$ agroindustri tempe $\longrightarrow$ pedagang pengecer $\longrightarrow$ pedagang kaki lima. Para pihak yang terkait dalam rantai pasok agroindustri tempe terdiri dari importir kedelai, agen kedelai, pedagang pengecer kedelai, pedagang pengecer tempe, pedagang kaki lima. Terdapat ketidakefisienan kinerja rantai pasok kedelai dan tempe pada atribut manajemen biaya dan manajemen aset. Pemasaran tempe saluran ketiga, pemasaran langsung ke konsumen akhir oleh agroindustri tempe adalah saluran pemasaran yang paling efisien.

\section{DAFTAR PUSTAKA}

Abidin Z, Harahab N, dan Asmarawati L. 2017. Pemasaran Hasil Perikanan. Tim UB Press. Malang.

Arikunto S. 2004. Prosedur Penelitian : Suatu Pendekatan Praktek. Rineka Cipta. Bandung.

Asmarantaka RW. 2014. Pemasaran Agribisnis (Agrimarketing). IPB Press. Bogor.

Azzaino Z. 1982. Pengantar Tataniaga Pertanian. Institut Pertanian Bogor. Bogor.

Bolstorff P. 2003. Supply Chain Excellence: a Handbook for Dramatic Improvement Using the SCOR Model. AMACOM. United State of America.
Hasyim AI. 2012. Tataniaga Pertanian. Universitas Lampung. Bandar Lampung.

Indrajit R, dan Djokopranoto R. 2002. Konsep Manajemen Supply Chain: Cara Baru Memandang Mata Rantai Penyediaan Barang. Grassindo. Jakarta.

Lestari S, Abidin Z, dan Sadar S. 2016. Analisis kinerja rantai pasok dan nilai tambah produk olahan Kelompok Wanita Tani Melati di Desa Tribudisyukur Kecamatan Kebun Tebu Lampung Barat. JIIA, 4 (1): 24-29. http://jurnal.fp.unila.ac.id/index.php/JIA/articl e/view/1211/1108. [ 11 Agustus 2018]

Mutakin dan Hubeis. 2011. Pengukuran kinerja manajemen rantai pasokan dengan pendekatan SCOR Model 9.0 (Studi Kasus di PT Indocement Tunggal Prakarsa Tbk). Jurnal Manajemen dan Organisasi, 2 (3): 89103. https://journal.ipb.ac.id/index.php/jmo/ article/view/14211 [16 November 2018]

Nilawati I. 2015. Analisis pemasaran tempe pada industri rumah tangga di Kota Palu. Jurnal Agrotekbis, 3 (4):498-506. http://jurnal. untad.ac.id/jurnal/index.php/Agrotekbis/articl e/view/5170/3943. [12 Desember 2018]

Noviantari K, Hasyim A.I, dan Rosanti N. 2015. Analisis rantai pasok dan nilai tambah Agroindustri Kopi Luwak di Provinsi Lampung. JIIA, 3 (1): 10-17. http://jurnal.fp. unila.ac.id/index.php/JIA/article/view/1012/ 917. [11 Agustus 2018]

Supply Chain Council. 2008. Supply Chain Operations Reference Model SCOR version 9.0 Metric. https://www.scribd.com/doc/ 4780677/Supply-Chain-Operation-SCOR9\#scribd. [16 November 2018]. 